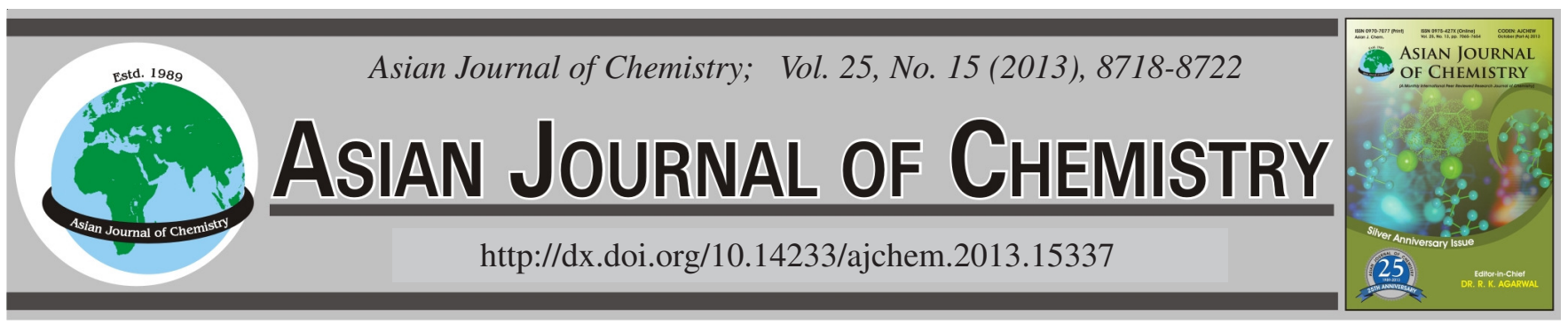

\title{
Characterization and Growth Optimization of a Novel Salt Resistant Pseudomonas putida Strain Zm Capable of Degrading Trichloroethylene by Cometabolism Under Aerobic Conditions
}

\author{
X. ZHANG ${ }^{1, *}$ and D. $\mathrm{XU}^{2}$ \\ ${ }^{1}$ Jiangsu Provincial Key Laboratory of Coastal Wetland Bioresources and Environmental Protection, Yancheng Teachers University, Yancheng \\ 224051, P.R. China \\ ${ }^{2}$ College of Life Science and Technology, Yancheng Teachers University, Yancheng 224051, P. R. China \\ *Corresponding author: Tel./Fax: +86 515 88233191; E-mail: yongshengzh@163.com
}

(Received: 18 February 2013;

Accepted: 27 August 2013)

AJC-14034

\begin{abstract}
A novel toluene-oxidizing strain capable of cometabolizing trichloroethylene was isolated and characterized. Combined with 16S rRNA sequence analysis, it was identified as Pseudomonas sp. It could grow with toluene as the sole carbon source. The analysis of the growth curve showed that $\mathrm{Zm}$ could reach the logarithmic phase within 8-10 h. Continuous sampling showed that toluene was exhausted within $1 \mathrm{~d}$. Finally $29.1 \%$ of trichloroethylene $(50 \mathrm{mg} / \mathrm{L})$ can be removed after incubation in mineral salt medium in the presence of $200 \mathrm{mg} / \mathrm{L}$ toluene for $3 \mathrm{~d}$ and $62.7 \%$ for $7 \mathrm{~d}$. The optimization of growth conditions was also conducted, the optimal growth conditions as the follows: carbon source toluene, at the concentration of $200-400 \mathrm{mg} / \mathrm{L}$, medium pH 7, temperature $28{ }^{\circ} \mathrm{C}$ and shaking speed $200 \mathrm{rpm}$. The tested strain $\mathrm{Zm}$ also showed substantial salt resistance including at $3.5 \% \mathrm{NaCl}$ concentration, indicating the potential application in bioremediation of coastal and marine trichloroethylene contaminants.
\end{abstract}

Key Words: Aerobic cometabolism, Biodegradation, Pseudomonas putida, Trichloroethylene, Salt tolerance.

\section{INTRODUCTION}

Trichloroethylene (TCE) is a halogenated volatile organic compound (VOC), which is believed to be carcinogenic and mutagenic ${ }^{1}$. It is considered a primary pollutant with $5 \mu \mathrm{g} / \mathrm{L}$ maximum contamination level allowed in drinking water.

Trichloroethylene has unique solvent properties which make it suitable for a wide range of industrial applications such as textile processing, refrigeration, lubricants and adhesives, along with the production of vinyl chloride, pharmaceuticals and insecticides ${ }^{1,2}$. Due to inappropriate disposal methods that are carried out, soil and groundwater contamination by trichloroethylene has become widespread. And this makes trichloroethylene become a recalcitrant groundwater pollutant ${ }^{3}$.

The toxic effects associated with trichloroethylene have raised a serious public concern over the extensive contamination problems and knowledge of its effective remedial process will be highly valuable. Several methods are available for remediation of trichloroethylene pollution, including physical processes, chemical control methods and bioremediation. Of these processes, bioremediation technology is preferred over other technologies because it allows for complete mineralization of trichloroethylene to harmless chemical forms, including carbon dioxide, water and chlorine ${ }^{4}$.
Up to date, although some researchers found direct degradation of trichloroethylene by some special organisms, such as endophyte of hybrid poplar ${ }^{5}$, the co-metabolic degradation of trichloroethylene was recognized as the most efficient mechanism $^{6}$. Besides methane-oxidizing bacteria ${ }^{7,8}$, toluene oxidizers and phenol oxidizers have also received tremendous attention ${ }^{9,10}$. These bacteria produce oxygenases in response to phenol $^{11}$ or toluene, which initiate the oxidative degradation and mineralization of trichloroethylene. Among the toluene oxidizers, the Pseudomonas putida strains F1 and Burkholderia cepacia G4 was widely employed to study the co-metabolic degrading of trichloroethylene $\mathrm{e}^{6,12,13}$.

Toxicity and inaccessibility of trichloroethylene to trichloroethylene degraders and extreme environmental limitations will hinder the bioremediation. This is the main problems encountered so far. To overcome this problem screening of strains with more advanced technologies from a wider range of habitats is essential. For remediation of marine ecosystem, salt resistance to some degree might be also essential.

\section{EXPERIMENTAL}

NB medium (/L) contains $10 \mathrm{~g}$ peptone, $5 \mathrm{~g}$ beef extract and $\mathrm{pH}$ value was adjusted to 7.0. NA plates were prepared with NB medium with $15 \mathrm{~g} / \mathrm{L}$ agar. 
MSM (/L) contains $1.0 \mathrm{~g} \mathrm{KH}_{2} \mathrm{PO}_{4}, 1.0 \mathrm{~g} \mathrm{~K}_{2} \mathrm{HPO}_{4}, 1.0 \mathrm{~g}$ $\mathrm{NH}_{4} \mathrm{NO}_{3}, 0.2 \mathrm{~g} \mathrm{MgSO}_{4} \cdot 7 \mathrm{H}_{2} \mathrm{O} ; 0.05 \mathrm{~g} \mathrm{Fe}_{2}(\mathrm{SO})_{3}$ and $0.05 \mathrm{~g}$; $\mathrm{CaCO}_{3} 0.02 \mathrm{~g}$ and $\mathrm{pH}$ value was adjusted to 7.0. Each of 120 $\mathrm{mL}$ serum bottles for fermentation contains $36 \mathrm{~mL} \mathrm{NB}, \mathrm{MSM}$ medium. All the media and materials are autoclaved at $121^{\circ} \mathrm{C}$ for $20 \mathrm{~min}$.

Characterization of $\mathbf{Z m}$ : Pure culture was stocked into a $1.5 \mathrm{~mL}$ eppendorf with the $20 \%$ glycerol at $-20^{\circ} \mathrm{C}$. A restreak with pure culture stock was performed on NB plate at $37^{\circ} \mathrm{C}$. After activation, $\mathrm{Zm}$ were submitted to plate culture and observation and physiological studies ${ }^{14}$. The 16S rRNA PCR and sequence analysis was carried out using modified protocols of reference ${ }^{15}$. The total DNA was extracted by DNA extraction kit from Hangzhou Sigmens Bioengineering Co. Ltd. (China). Two primers annealing at the 5' and 3' end of the $16 \mathrm{~S}$ rRNA gene were:

Forward primer (F): 5'AGA GTT TGA TCC TGG CTCAG 3' Reverse primer (1492R): 5' TAC GGY TAC CTT GTT ACG ACT T 3'

The PCR was carried out accordingly. PCR products were sent to Shanghai Sagon Bioengineering Co. Ltd for sequencing. Afterwards, the partial rDNA sequences were analyzed using a BLAST search algorithm to estimate the degree of similarity to other rDNA sequences obtained from the NCBI/GenBank (http://www.ncbi.nlm.nih.gov/BLAST/) and the phylogenetic tree was also drawn using strains in the GenBank.

Acclamation to toluene: $\mathrm{Zm}$ pure culture was acclamated as the following procedures: it was enriched in the NB medium at $37^{\circ} \mathrm{C}$ for $24 \mathrm{~h}$, then centrifuged to collect the cells, suspended in normal saline and inoculated in MSM plus $50 \mathrm{mg} / \mathrm{L}$ toluene and cultured at $28^{\circ} \mathrm{C}$ for $72 \mathrm{~h}$ as the first subculture, 4 $\mathrm{mL}$ inocula of the first subculture was inoculated in MSM plus $100 \mathrm{mg} / \mathrm{L}$ toluene and cultured at $28{ }^{\circ} \mathrm{C}$ for $72 \mathrm{~h}$ as the second subculture and then inoculated in that plus $200 \mathrm{mg} / \mathrm{L}$ and culture at the same conditions as third subculture. Afterwards, subculture was conducted every week.

Growth curve determination: The 3rd subculture was inoculated in $150 \mathrm{~mL}$ serum bottles containing MSM plus 200 $\mathrm{mg} / \mathrm{L}$ toluene and cultured on shaking table at $28^{\circ} \mathrm{C}$. The culture broth was sampled every $4 \mathrm{~h}$ and the $\mathrm{OD}_{600 \mathrm{~nm}}$ of the broth was determined. The growth curve was drawn with Origin 8.0 software.

\section{General procedure}

Evaluation of bioremoval efficiency: Exact $4 \mathrm{~mL}$ of each acclamated pure culture was inoculated to bottles containing $36 \mathrm{~mL}$ MSM (according to the results of 1.2) plus $200 \mathrm{mg} / \mathrm{L}$ toluene and $50 \mathrm{mg} / \mathrm{L}$ trichloroethylene and cultured at $28^{\circ} \mathrm{C}$ and $150 \mathrm{rpm}$ for $24,48,72,96,120$ and $168 \mathrm{~h}$ to evaluate the removal efficiency and biodegradation rate of trichloroethylene. Controls were set without inoculation.

Optimization of cultivation conditions: (1) Carbon sources: Exact $4 \mathrm{~mL}$ of pure culture was inoculated to bottles containing $36 \mathrm{~mL}$ MSM plus $200 \mathrm{mg} / \mathrm{L}$ toluene, methanol, acetone and phenol and cultured at $28^{\circ} \mathrm{C}$ and $200 \mathrm{rpm}$ for $24 \mathrm{~h}$. All the cultures was acquired by acclamation with corresponding carbon source individually as 1.3 . The $\mathrm{OD}_{600 \mathrm{~nm}}$ of the broth was determined individually. (2) Concentration of toluene: Exact $4 \mathrm{~mL}$ acclamated pure culture was inoculated to bottles containing $36 \mathrm{~mL}$ MSM plus 200, 300, 400, 500 and $600 \mathrm{mg} / \mathrm{L}$ toluene and cultured at $28^{\circ} \mathrm{C}$ and $200 \mathrm{rpm}$ for $24 \mathrm{~h}$. The $\mathrm{OD}_{600}$ $\mathrm{nm}$ of the broth was determined individually. (3) $\mathrm{pH}$ value: Exact $4 \mathrm{~mL}$ acclamated pure culture was inoculated to bottles containing $36 \mathrm{~mL}$ MSM plus $200 \mathrm{mg} /$ toluene, with the $\mathrm{pH}$ value adjusted to $3,5,7,9,11,12$ and cultured at $28^{\circ} \mathrm{C}$ and $200 \mathrm{rpm}$ for $24 \mathrm{~h}$. The $\mathrm{OD}_{600 \mathrm{~nm}}$ of the broth was determined individually. (4) Salinity: Exact $4 \mathrm{~mL}$ acclamated pure culture was inoculated to bottles containing $36 \mathrm{~mL}$ MSM plus $200 \mathrm{mg} /$ toluene, with the $\mathrm{NaCl}$ adjusted to $0.5,3.5,8,10,12.5$ and $15 \%$ and cultured at $28^{\circ} \mathrm{C}$ and $200 \mathrm{rpm}$ for $24 \mathrm{~h}$. The $\mathrm{OD}_{600 \mathrm{~nm}}$ of the broth was determined individually. (5) Temperature: Exact $4 \mathrm{~mL}$ acclamated pure culture was inoculated to bottles containing $36 \mathrm{~mL} \mathrm{MSM}$ plus $200 \mathrm{mg} / \mathrm{L}$ toluene and $50 \mathrm{mg} / \mathrm{L}$ trichloroethylene and cultured at $15^{\circ} \mathrm{C}, 20^{\circ} \mathrm{C}, 25^{\circ} \mathrm{C}, 28^{\circ} \mathrm{C}, 30^{\circ} \mathrm{C}, 35^{\circ} \mathrm{C}, 45^{\circ} \mathrm{C}$ and $200 \mathrm{rpm}$ for $24 \mathrm{~h}$. (6) Dissolved oxygen concentration: The dissolved oxygen concentration was adjusted by shaking speed of shaker. Exact $4 \mathrm{~mL}$ acclamated pure culture was inoculated to bottles containing $36 \mathrm{~mL}$ MSM plus $200 \mathrm{mg} / \mathrm{L}$ toluene and $50 \mathrm{mg} / \mathrm{L}$ trichloroethylene and cultured at $28^{\circ} \mathrm{C}$ and 140,160 , 180, 200 and $220 \mathrm{rpm}$ for $24 \mathrm{~h}$.

Detection method: Residue trichloroethylene and toluene contents were measured by gas chromatograph (GC, Agilent, 6890N, Agilent Technologies Co., Ltd, China) equipped with a flame ionization detector (FID) and a capillary column (HP$5 ; 30 \mathrm{~m} \times 0.53 \mu \mathrm{m}$ I.D. with a stationary-phase film thickness of $0.88 \mu \mathrm{m})$. Samples were withdrawn in accordance to the sampling scheme using sterilized syringes. About $1 \mathrm{~mL}$ of the liquid sample was then injected into the amber vial (WHEATON) and secured with PTFE/silicone liner (WHEATON) using crimper. One microliter of liquid samples was injected by the autosampler injector (7638 Series, Agilent Technologies Co., Ltd., China) equipped with a tapered microsyringe (5181-1267, Hamilton Company, USA). The tapered microsyringe in the autosampler was preinjected with solvent (ethanol) twice before the injection of the sample into the GC and two postinjections were done after the injection. Nitrogen was used as carrier gas at a flow rate of $20 \mathrm{~mL} / \mathrm{min}$. The flow rates of hydrogen gas and synthetic air were 40 and $400 \mathrm{~mL} / \mathrm{min}$, respectively. The inlet and detector temperatures were 260 and $280^{\circ} \mathrm{C}$, respectively. The column temperature was programmed as initial temperature, $40^{\circ} \mathrm{C}$ (hold for $2 \mathrm{~min}$ ), then incrementally increased at $12{ }^{\circ} \mathrm{C} / \mathrm{min}$ to $300{ }^{\circ} \mathrm{C}$, then hold for $10 \mathrm{~min}$.

\section{RESULTS AND DISCUSSION}

Characterization of strain $\mathrm{Zm}$ : $\mathrm{Zm}$ could form round colonies $c a .3 \mathrm{~mm}$ in diameter on beef-peptone agar plate and blood agar plate, but cannot form clear haemolytic circles after cultivation for $2 \mathrm{~d}$ on the blood agar plates. Zm was gramnegative and rod-shaped bacteria. The sequencing analysis of $\mathrm{Zm}$ using the $16 \mathrm{~S}$ rRNA gene nucleotide sequences data showed that this strain had the highest homology (over $99 \%$ ) with Pseudomonas putida or Pseudomonas plecoglossicida (Fig. 1).

Combined with other results of morphological, physiological and biochemical tests (Table-1), Zm was identified as Pseudomonas putida. This strain could grow well in $10 \%$ $\mathrm{NaCl}$ supplemented $\mathrm{NB}$, showing good salt resistance. 


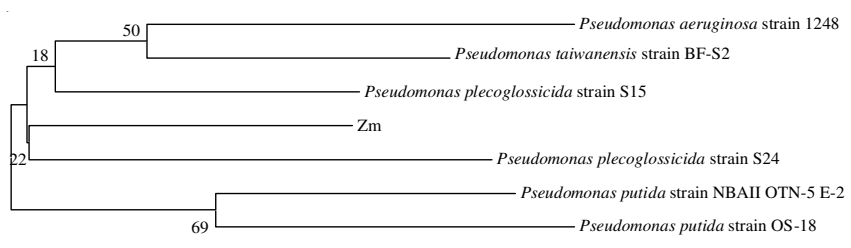

Fig. 1. Neighbor-joining trees based on the sequences of $16 \mathrm{~S}$ rRNA gene. [Numbers on the tree represent bootstrap value (1000 replications)]

\begin{tabular}{|c|c|}
\hline \multicolumn{2}{|c|}{$\begin{array}{l}\text { TABLE-1 } \\
\text { OTHER MORPHOLOGICAL, PHYSIOLOGICAL AND } \\
\text { BIOCHEMICAL IDENTIFICATIONS OF Zm }\end{array}$} \\
\hline Tested items & Results \\
\hline Endospore & $-\mathrm{ve}$ \\
\hline Flagella & +ve, mobile \\
\hline Pigment producing in NB & - ve \\
\hline Oxydase & $+\mathrm{ve}$ \\
\hline Contact enzyme & $+\mathrm{ve}$ \\
\hline Aerobic/anaerobic & Aerobic \\
\hline Citrate utilization test & $+\mathrm{ve}$ \\
\hline sodium malonate utilization & $+\mathrm{ve}$ \\
\hline Tartrate utilization & $+\mathrm{ve}$ \\
\hline Nitrate reduction test & $+\mathrm{ve}$ \\
\hline Glucose fermentation & +ve, acid produced \\
\hline Lactose fermentation & +ve, acid produced \\
\hline Lactic acid fermentation & +ve, acid produced \\
\hline Sorbitol fermentation & +ve, acid produced \\
\hline Dulcitol fermentation & +ve, acid produced \\
\hline Arabinose fermentation & $-\mathrm{ve}$ \\
\hline Esterase & $-\mathrm{ve}$ \\
\hline Urease & $+\mathrm{ve}$ \\
\hline V.P. & $-\mathrm{ve}$ \\
\hline Methyl red test & $-\mathrm{ve}$ \\
\hline Glutin liquefaction & $+\mathrm{ve}$ \\
\hline $\mathrm{NB}+0.5 \%$ salt & $+\mathrm{ve}$ \\
\hline $\mathrm{NB}+2 \%$ salt & $+\mathrm{ve}$ \\
\hline $\mathrm{NB}+4 \%$ salt & $+\mathrm{ve}$ \\
\hline $\mathrm{NB}+6 \%$ salt & $+\mathrm{ve}$ \\
\hline $\mathrm{NB}+8 \%$ salt & $+\mathrm{ve}$ \\
\hline $\mathrm{NB}+10 \%$ salt & $+\mathrm{ve}$ \\
\hline
\end{tabular}

Growth curve: The growth curve in MSM plus toluene was determined by continuous samplings. It could be concluded from Fig. 2 that based on optical density at $600 \mathrm{~nm}$, the $\mathrm{Zm}$ showed similar growth curve with Escherichia coli. It could reach the $\log$ phase at about $8 \mathrm{~h}$ and death phase at about $20 \mathrm{~h}$.

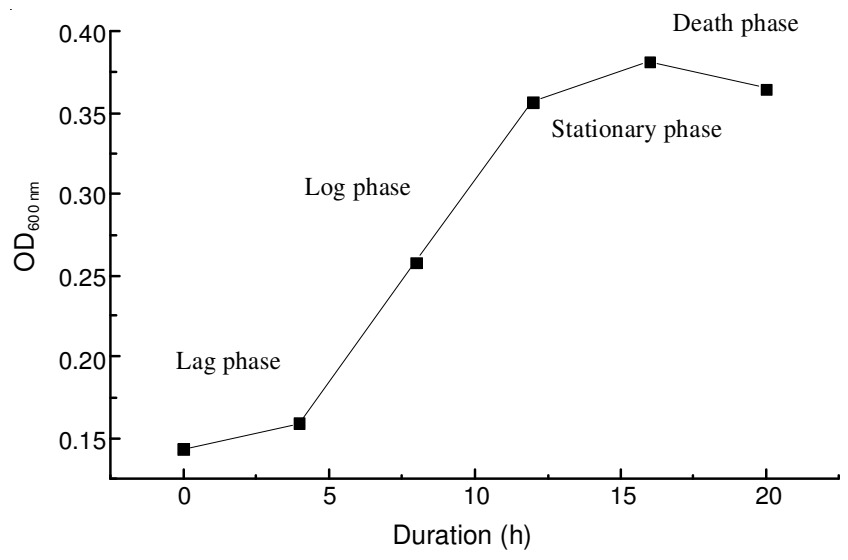

Fig. 2. Growth curve in MSM plus toluene
Then in the following experiments, all the acclamated pure cultures were inoculated at $8 \mathrm{~h}$.

Degrading characteristics study: Table- 2 showed that toluene as the substrate was consumed very quickly and was used up within $24 \mathrm{~h}$. The residual trichloroethylene decreased slowly. About $29.1 \%$ of trichloroethylene $(50 \mathrm{mg} / \mathrm{L})$ can be removed after incubation in mineral salt medium in the presence of $200 \mathrm{mg} / \mathrm{L}$ toluene for $3 \mathrm{~d}$ and $62.7 \%$ for $7 \mathrm{~d}$, indicating that although the toluene was exhausted, the dioxygenase produced by $\mathrm{Zm}$ were still working for degradation of trichloroethylene.

\section{Optimization of growth conditions}

Effect of medium conditions on growth of Zm: Fig. 3 shows different medium conditions, i.e., carbon sources, toluene concentrations, initial $\mathrm{pH}$ value of $\mathrm{MM}$ and $\mathrm{NaCl}$ concentration, on growth $\mathrm{Zm}$ measured by optical density value at $600 \mathrm{~nm}$. It can be concluded from Fig. 3a that toluene was the best sole carbon source, significantly differing from the other three organic matters. Phenol could also work as the sole carbon source, but the growth of $\mathrm{Zm}$ was much slower than using toluene. Methanol and acetone were not suitable carbon source for $\mathrm{Zm}$.

Toluene concentration also influenced the growth of $\mathrm{Zm}$, but not so obviously as carbon source did. Judging from Fig. $3 \mathrm{~b}$, with the rising of toluene concentration, the optical density values also rose, reaching the climax at $400 \mathrm{mg} / \mathrm{L}$. Then with the rising of toluene concentration, the growth went down sharply. It seemed that $200-400 \mathrm{mg} / \mathrm{L}$ toluene were all appropriate concentrations for $\mathrm{Zm}$ growth, with no significant differences. To shorten the acclamation period, $200 \mathrm{mg} / \mathrm{L}$ were preferred.

It can be seen from Fig. $3 \mathrm{c}$ that $\mathrm{pH}$ value of MM also influenced the growth of $\mathrm{Zm}$. Neutral conditions of MM (pH $=7$ ) were the best conditions for $\mathrm{Zm}$.

Fig. 3d illustrates the changing trend of OD values at 600 $\mathrm{nm}$ of $\mathrm{Zm}$ when subjected to different $\mathrm{NaCl}$ concentrations. With the rising of $\mathrm{NaCl}$ concentration from 0.5 to $3.5 \%$ (the average salinity of the ocean), the optical density value didn't change remarkably, dropping from 0.42 to 0.35 , indicating that $\mathrm{Zm}$ could grow well in seawater prepared medium and thus good potential of employment in bioremediation of toluene and trichloroethylene in marine ecosystem. Even at higher concentrations $(>8 \%)$, Zm could hardly grow.

Effect of environmental conditions on growth of $\mathbf{Z m :}$ Environmental factors especially temperature and dissolved oxygen concentration are also considered important for the growth of environmental bacteria. As shown in Fig. 4A, with the continuous increasing of temperature, optical density value rose to climax at $28{ }^{\circ} \mathrm{C}$ and then dropped but there were no significant differences among $25,28,30$ and $35^{\circ} \mathrm{C}$, showing that $\mathrm{Zm}$ could grow rigorously at the temperature range at $25-30{ }^{\circ} \mathrm{C}$. But at $45{ }^{\circ} \mathrm{C}$, the optical density value dropped significantly to below 0.1 , indicating $\mathrm{Zm}$ could not grow at normal speed at high temperature at $45{ }^{\circ} \mathrm{C}$ or above. But dissolved oxygen concentration (shaking speed) didn't influence the growth significantly, although the $\mathrm{OD}_{600 \mathrm{~nm}} \mathrm{kept}$ increasing with increment of shaking speed (Fig. 4B). Then $200 \mathrm{rpm}$ should be a suitable speed for cultivation of $\mathrm{Zm}$. 


\begin{tabular}{|c|c|c|c|c|c|}
\hline \multicolumn{6}{|c|}{$\begin{array}{c}\text { TABLE-2 } \\
\text { BIOREMOVAL EFFICIENCY OF TOLUENE AND TRICHLOROETHYLENE BY Zm }\end{array}$} \\
\hline & \multirow{2}{*}{$\begin{array}{l}\text { Toluene bioremoval } \\
\text { efficiency }(\%)\end{array}$} & \multirow{2}{*}{$\begin{array}{l}\text { TCE concentration } \\
(\mathrm{mg} / \mathrm{L})\end{array}$} & \multicolumn{3}{|c|}{ TCE removal efficiency $(\%)$} \\
\hline & & & Total & Biotic & Abiotic \\
\hline 1dck & 100 & 26.5 & 47.0 & 0.0 & 47.0 \\
\hline $1 \mathrm{~d}$ & 100 & 23.0 & 54.0 & 13.3 & 40.8 \\
\hline 3dck & 100 & 25.7 & 48.5 & 0.0 & 48.5 \\
\hline $3 d$ & 100 & 18.2 & 63.5 & 29.1 & 34.4 \\
\hline $5 \mathrm{dck}$ & 100 & 26.8 & 46.4 & 0.0 & 46.4 \\
\hline $5 \mathrm{~d}$ & 100 & 17.0 & 66.0 & 36.5 & 29.4 \\
\hline $7 \mathrm{dck}$ & 100 & 25.0 & 50.1 & 0.0 & 50.1 \\
\hline $7 \mathrm{~d}$ & 100 & 9.3 & 81.4 & 62.7 & 18.7 \\
\hline
\end{tabular}
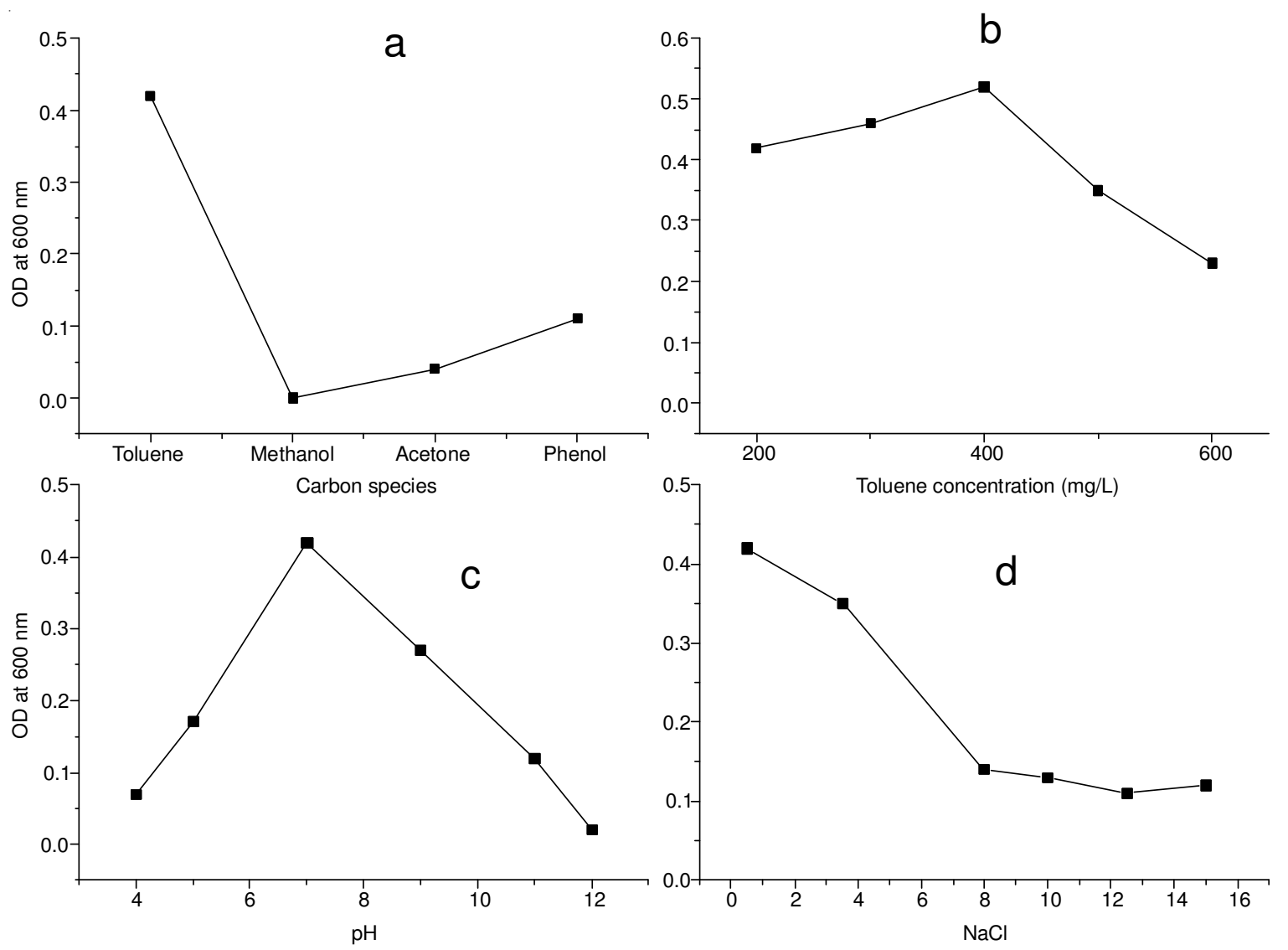

Fig. 3. Effect of medium conditions on growth of $\mathrm{Zm}$. (a) Carbon sources, (b) Toluene concentration, (c) $\mathrm{pH}$, (d) $\mathrm{NaCl}$ concentration. All the data were average values of triplicates. To make the figures more concise, the error bars were not given
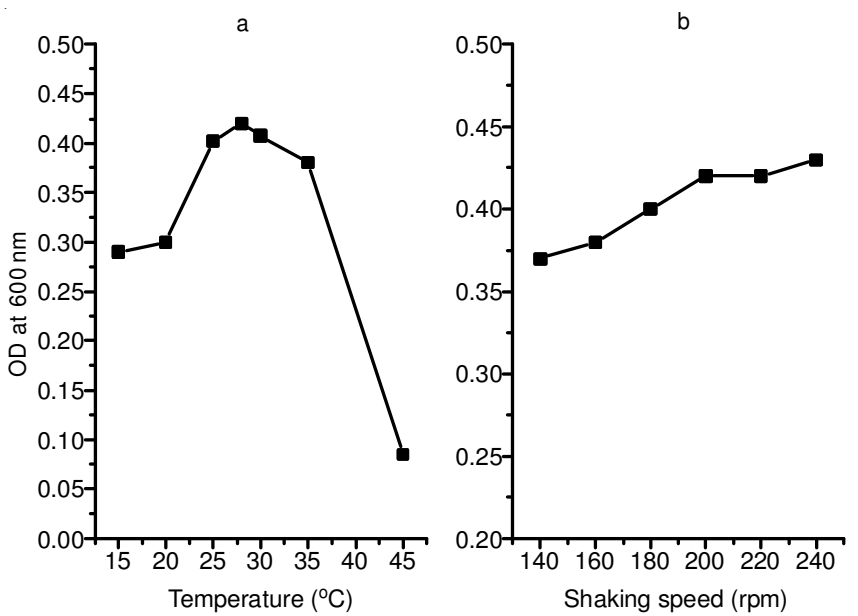

Fig. 4. Effects of environmental conditions on growth of $\mathrm{Zm}-1$. (All the data were average values of triplicates. To make the figures more concise, the error bars were not given)

\section{Conclusion}

A novel toluene-oxidizing strain $\mathrm{Zm}$ capable of cometabolizing trichloroethylene was isolated and identified. Combined with $16 \mathrm{~S}$ rRNA sequence analysis, it was identified as Pseudomonas putida. The analysis of the growth curve showed that $\mathrm{Zm}$ could reach the logarithmic phase within 8$10 \mathrm{~h}$. It could remove trichloroethylene efficiently using toluene as the sole carbon source. The optimal growth conditions as the follows: carbon source toluene, at the concentration of 200$400 \mathrm{mg} / \mathrm{L}$, medium $\mathrm{pH} \mathrm{7.0,} \mathrm{temperature} 28{ }^{\circ} \mathrm{C}$ and shaking speed $200 \mathrm{rpm}$. The tested strain $\mathrm{Zm}$ also showed substantial salt resistance including at $3.5 \% \mathrm{NaCl}$ concentration.

Reliability of the experimental system: For toluene and trichloroethylene are both volatile, some researchers developed special instruments, including Erlenmeyer flasks with specifically prepared glass stoppers for cultivation of trichloroethylene co-metabolic degraders ${ }^{16}$. In this study, only common 
silicon glass serum bottles were used. After injection of toluene and trichloroethylene, the serum bottles were quickly sealed with bottle sealed with Teflon-faced butyl rubber stoppers and aluminum crimps and inverted for cultivation to prevent possible abiotic losses of toluene and trichloroethylene by volatility and absorption of glass. The residual trichloroethylene of the blanks kept constant (unreported in this study), the closed system was reliable.

Bioremoval efficiency: Pseudomonas putida is a frequently used species in environmental bioremediation ${ }^{4,17}$. Our P. putida strain $\mathrm{Zm}$ could grown in mineral media with toluene as the sole carbon source and $29.1 \%$ of trichloroethylene $(50 \mathrm{mg} / \mathrm{L})$ can be removed after incubation in mineral salt medium in the presence of $200 \mathrm{mg} / \mathrm{L}$ toluene for $3 \mathrm{~d}$ and $62.7 \%$ for $7 \mathrm{~d}$, which indicating that this strain could remove trichloroethylene in water body efficiently in a short time. The trichloroethylene concentration used in our study was higher than most other literatures, for instance, $5 \mathrm{mg} / \mathrm{L}^{18}, 0.2-20 \mathrm{mg} / \mathrm{L}^{10}$, thus it seemed that the removal efficiency of trichloroethylene by $\mathrm{Zm}$ was comparatively low. Next the optimization of degrading conditions (nutrimental and environmental) is essential for further improvement in trichloroethylene removal efficiency.

Importance of salt resistance of trichloroethylene degraders: Trichloroethylene contaminations sometimes take place in saline environments, including coastal wetland ${ }^{19}$ and saline sediments, seawater and saline wastewater. Under these conditions, salt resistance of trichloroethylene degrading microorganisms shows its importance in in situ trichloroethylene bioremediation. However, salt resistant trichloroethylene degraders are rarely reported up to date. In present study, $\mathrm{Zm}$ could grow vigorously at $3.5 \% \mathrm{NaCl}$ concentration as well as degrading trichloroethylene very efficiently. It should be of great potential to be employed in toluene and trichloroethylene remediation in the saline environments as above and deserves further study on the mechanisms of salt resistance with toluene as growth substrate or/and trichloroethylene.

\section{ACKNOWLEDGEMENTS}

This research was supported by National Natural Science Foundation of China (Grant No. 10905035) and Open Project of Jiangsu Provincial Key Laboratory of Coastal Wetland Bioresources and Environmental Protection and Jiangsu Key Laboratory for Bioresources of Saline Soils.

\section{REFERENCES}

1. P. Pant and S. Pant, J. Environ. Sci., 22, 116 (2010).

2. A.K. Shukla, S.N. Upadhyay and S.K. Dubey, Crit. Rev. Biotechnol., (2012) online available.

3. G.J. Chee, Talanta, 85, 1778 (2011).

4. H. Cheng and H. Jin, Shanghai Environ. Sci., 16, 20 (1997) (in Chinese).

5. J.W. Kang, Z. Khan and S.L. Doty, Appl. Environ. Microbiol., 78, 3504 (2012).

6. J. Liu, T. Amemiya, Q. Chang, Y. Qian and K. Itoh, Biodegradation, 23, 683 (2012).

7. C. Powell, G. Nogaro and A. Agrawal, Biodegradation, 22, 527 (2011).

8. C.L. Powell and A. Agrawal, Wetlands, 31, 45 (2011).

9. Z. Yi and T.J. Hwa, J. Biotechnol., 162, 274 (2012).

10. J. Ruzicka, M. Dvorackova and M. Koutný, Asian J. Chem., 23, 4255 (2011).

11. Y. Zhang and J.H. Tay, J. Biotechnol., 162, 274 (2012).

12. D.K. Thompson, K. Chourey, G.S. Wickham, S.B. Thieman, N.C. VerBerkmoes, B. Zhang, A.T. McCarthy, M.A. Rudisill, M. Shah and R.L. Hettich, BMC Genomics, 11, 311 (2010).

13. A.S. Landa, E.M. Sipkema, J. Weijma, A. Beenackers, J. Dolfing and D.B. Janssen, Appl. Environ. Microbiol., 60, 3368 (1994).

14. G.M. Garrity, D.J. Brenner and N.R. Krieg, Bergey's Manual of Systematic Bacteriology: Springer (2005).

15. S.C. Lee, S.J. Lee, S.H. Kim, I.H. Park, Y.S. Lee, S.Y. Chung and Y.L. Choi, Bioresour. Technol., 99, 2288 (2008).

16. J. Xi, H. Hu, H. Zhu and Y. Qian, Biochem. Eng. J., 23, 123 (2005).

17. J. Liu, T. Amemiya, Q. Chang, Y. Qian and K. Itoh, Biodegradation, 23, 683 (2012).

18. X. Wang, Y. Zhang, S. Han, Y. Wang and H. Li, Ecol. Environ., 17, 1778 (2008) in Chinese.

19. M.M. Lorah, L.D. Olsen, D.G. Capone and J.E. Baker, Bioremed. J., 5, 101 (2001). 